Наталія Шерстюк

ORCID: https://orcid.org/0000-0002-2755-9627

DOI 10.31558/1815-3070.2020.40.2.15

УДК 821.111(73)-32По

\title{
МОТИВ БОЖЕВІЛЛЯ ЯК НЕВІД'СМНИЙ ЧИННИК ХРОНОТОПУ В НОВЕЛІ «СИСТЕМА ДОКТОРА СМОЛЛА І ПРОФЕСОРА ПІРІА»
}

\author{
E. A. ПО
}

У статті розглядається проблема психічних розладів та аналізуються особливості часопростору в новелі «Система доктора Смолла і професора Піріа» американського письменника XIX століття Едгара Аллана По. Метою статті є трунтовний аналіз художнього хронотопу як особливого способу впливу на читача та виокремлення особливостей часу і простору в аналізованому творі. Грунтовно описується дуальний хронотоп та осмислюється художня реалізачія випадків практичної психіатрії. Основним видом хронотопу в "психологічній» новелі є реальний та історичний хронотоп, автор неодноразово акцентує увагу на просторових топосах, зокрема божевільні, щзо виформовують неповторний авторський стиль.

Ключові слова: Е. По, "Система доктора Смолла і професора Піріа», мотив, хронотоп, час, простір, наратив, топос, локус, божевілля.

Едгар По (Edgar Allan Poe (1809-1849)) є одним із представників американського романтизму, котрий і нині залишається одним з найпопулярніших письменників. Е. По - зачинатель детективного жанру, який згодом став одним із центральних напрямів у літературі, і перший американський письменник, що почав пр ацювати у жанрі «short story». Його твори читають і пер ечитують все нові й нові покоління у всьому світі. Творчість великого американського письменника стала надбанням світової культури. 3-під пера митця вийшли такі твори, як-от: «Падіння дому Ашерів» (1839), «Провалля і маятник» (1842), «Чорний кіт» (1843), «Серце виказало» та ін.

Дослідники всебічно розглядали твор чість митця (Ковалев Ю., Кларк Дж., Меєрс Дж., Дмитр ієва Л., Павлова М., Ніколюкін А., Осипова Е. та ін.), однак багато питань ще потребують детального дослідження.

Метою дослідження $\epsilon$ грунтовний аналіз художнього хронотопу як особливого способу впливу на читача та виокремлення особливостей часу і простору в аналізованому творі.

Цікавим твором, у якому грунтовно описується дуальний хронотоп, є новела Едгара Аллана По «Система доктора Смолла і професора Піріа», що є досить коротким і складається із маленьких історій про цікаві випадки практичної психіатрії. У творі йдеться про психіатричну лікарню на півдні Фр анції, у якій людей лікують за допомогою нестандартних методів. Оповідь у творі ведеться від імені невідомого наратора, котрому закортіло ознайомитися із методами л ікування в окремо взятій божевільні, і він за рекомендацією попутника потрапляє у цей заклад, знайомиться із головним лікарем і має змогу поспіл куватися із людьми, котрих зустрічає на своєму шляху. 
Художній час і художній простір новели стають найважливішими катего ріями внутрішнього світу, що моделюється письменником. Саме просторовочасовий континуум відтворює параметри світу, спроєктованого автором, визначаючи специфіку жанру, стилю тощо, а також виконує імагогічну, характерологічну функцію, адже образ у літературі «завжди істотно хронотопічний» (Бах тин 235). Хронотоп фор мує певне уявлення про цілісну картину світу, оскільки художній образ «своїм змістом відтворює просторово-часову картину світу, до того ж в ії̈ символіко-ідеологічному, ціннісному аспекті» (Роднянская 1174).

Хронотоп у новелі «Система доктора Смолла і пр офесора Піріа» Е. По $\epsilon$ напрочуд важливим, адже саме час і простір відіграють значну роль у творах психологічного типу. Із самого початку час і простір закодовується автором, йдеться про XIX століття, події розгортаються у Франції, яка стає для письменника тим екзотичним локусом, де можуть відбуватися подіï. «During the autumn of 18-, while on a tour through the extreme southern provinces of France, my route led me within a few miles of a certain Maison de Sante or private mad-house» (Poe). Час і простір не деталізується автором, відтворюються будні пересічного безіменного героя, який мандрує півднем Франції. Науковець Л. Є. Кройчик вважає, що визначення місця події на початку оповідання відіграє стандартну роль введення читачів у художній світ твору, виконує роль «стандартних атрибутів» (Кройчик 135). На нашу думку, автор намагається ввести читача у курс подій, що виконує прогностичну функцію, оскільки простір виформовує сюжет i, вужче, героя, котрий $є$ одиницею художнього світу (у цьому оповіданні - це екзотич ний для американської літератури топос півдня Франції, звичайний пер есічний герой, через призму якого бачаться події). Тобто, побутовий простір уводиться у текст ще із початку оповіді: йтиметься про приватну лікарню для душевнохворих, яка розмітилася у замку, екскурсія оповідача лікарнею, обід у їдальні тощо, що є частиною реального хронотопу.

У новелі зустрічається кілька видів хронотопу, основними із яких є історично-побутовий та особистісний, що виформовує кожну окрему особистість та відтворює індивідуальні зрушення у людській психіці. Для художнього простору новели характерні й готичні мотиви, які стають у творах такого типу константними: описи приміщення, нагнітання атмосфери страху і жаху, таємниця, нед осказаність тощо. Особистісний тип хронотопу употужнено психологічними мотивами, які й визначають екзистенцію особистості. Психопатичне божевілля веде у Е. По до розпаду особистості. Один із дослідників, філософ М. Фуко, котрий досліджував явища божевілля у світовому мистецтві (полотна I. Боша, А. Дюрера, П. Брейгеля, твори С. Бранта, Е. Роттердамського та ін.) зазначав, що у гуманістів «безумство обмежується Всесвітнім дискурсом. «Там він стає ... обеззброєним. Це змінює масштаб: народжений у серцях людей, він керує та змінює їхню поведінку. Сформоване у такий спосіб божевілля перетворюється на іронію і належить до «критичної свідомості людини» (Foucault 27). Ключову роль відіграє ефект відсторонення автора і читача, спроба не залучення, а сп остереження за чужим. На думку філософа, протистояння трагічного досвіду та критичної свідомості пр изведе до перемоги останньої, мовний досвід витіснить 
візуально-пластичний. Але неявна присутність трагічного досвіду божевілля буде відчуватися під оболонкою критичної свідомості, виведена на повер хню в добу історичних катаклізмів, призводячи до вибуху (Foucault 26-27). На нашу думку, у представленій новелі втілено обидва чинники божевілля, що тісно переплітаються між собою.

У новелі відтворюється реальний локус - психіатрична лікарня, у якій пр актикується унікальна система лікування. Наратор чув про неї від багатьох пар изьких лікарів, тому й намагається потрапити у закритий простір і сам усе побачити. «I had heard, at Paris, that the institution of Monsieur Maillard was managed upon what is vulgarly termed the «system of soothing» - that all punishments were avoided - that even confinement was seldom resorted to - that the patients, while secretly watched, were left much apparent liberty, and that most of them were permitted to roam about the house and grounds in the ordinary apparel of persons in right mind» (Роe). Оповідач потрапляє до лікарні за рекомендацією попутника, котрий був знайомий з головним лікарем, але сам остерігався таких місць, тому туди їхати не захотів. Новела має досить реальний, конкретний простір, з характерною для нього точністю зображення місця й часу перебування в лікар ні. Наратор відтворює події з позиції ретр оспекції, переповідає, що він бачив і за чим спостерігав у минулому: оповідач «вирушає в минуле, в невідомість, щоб відновити події» (Ковалев 121). Ретроспективність у новелі - категорія не визначена, не достовірна, оскільки кожна людина, з якою познайомився оповідач, не $\epsilon$ тією, що здається: хворі здійняли бунт і захопили управління лікарнею, медич ний персонал опинився під вартою.

У цій новелі мотиви гри, ірраціональності стають маркерами реального часопростору та проявляються дуально. У творі стирається межа між хворобою та здоровим глуздом, оскільки ці категорії тісно взаємопов'язані. Мотив «хворої / здорової свідомості» $є$ константним у новелах Е. По психологічного різновиду. Божевілля у сюжеті подано у формі гри: це і наявність правил, певноїлогіки та свободи вибору. Саме за цими параметрами позиціонуються герої: і хвор і, i л iкарі, кожен одягає власну маску та грає певну роль. Часом незр озуміло, де межа у різних станах свідомості, тому логіка і хаос у новелі тісно переплітаються, вивільняючись у домінантний принцип особистісного хронотопу - роздвоєння особистості, що породжує туманність та невизначеність.

Реальний час у новелі описується досить побіжно, оскільки в оповіді відсутні явні маркери, які б відтворювали час твору. Персонажі розповідають пр о себе та власні психічні зрушення у третій особі. «The keepers and kept were soon made to exchange places. Not that exactly either for the madmen had been free, but the keepers were shut up in cells forthwith, and treated, I am sorry to say, in a very cavalier manner» (Рoe). Оповідач бачиться хворими як наївний випадковий св ідок, що не здатний відрізнити хворих від здорових. Дивним $є$ і той факт, що навіть після повернення хворих у свої палати, після повернення оповідача до звич ного життя, він продовжує шукати інформацію про медичні праці доктора Смолла та професора Піріа, які у творі є певними фікціями. «I am forced to acknowledge my ignorance, I replied; but the truth should be held inviolate above all 
things. Nevertheless, I feel humbled to the dust, not to be acquainted with the works of these, no doubt, extraordinary men. I will seek out their writings forthwith, and peruse them with deliberate care. Monsieur Maillard, you have really - I must confess it - you have really - made me ashamed of myself!» (Роe). На нашу думку, автор актуалізує проблему божевілля і на рівні оповідача, котрий не здатний відрізнити правду від брехні або вигадки, що тягне за собою неподільні сть по няття «здоровий глузд / божевілля».

Новела побудована на протиставленні реального та ірреального хронотопів, які, поєднуючись, виформовують складний художній світ творів. Ірреальність пр оєктується через готичну традицію, характерну для оповіді. Лікар ня стає тим загадковим, ірреальним місцем, яке наче й існує насправді, але подається загадково, туманно. Лікарня стає важливим часопросторовим топосом, оскільки це класичне місце розвитку подій у готичному творі, що характеризує героїв та сприяє розвитку сюжету. Топос «замкненої лікарні», містить певну таємницю, яку читачеві потрібно осягнути. Опис лікарні характеризується утаємниченістю: будівля була занедбаною і вселяла певний страх, дорога, що вела до будинку, проходила через сиру гущавину. «It was a fantastic chateau, much dilapidated, and indeed scarcely tenantable through age and neglect. Its aspect inspired me with absolute dread, and, checking my horse, I half resolved to turn back. I soon, however, grew ashamed of my weakness, and proceeded» (Рое). Наратор описує клініку «Maisons de Santé» як незвичайне місце, де лікуються люди освічені та заможні, родичі яких можуть заплатити за лікування. Захопивши владу, ніхто з пацієнтів навіть не спробував втекти, а, навпаки, вони побудували спр аведливе суспіль ство та зажили нормальним життям без процедур, де кожен один одного підтримував. Психічно хворими вони не перестали бути, але ніякої шкоди не пр иносили. Хворий лікар Майяр зміг досить вдало керувати хворими людьми.

Художній простір новели чітко структурований і диференційований письменником на два експліцитно антагоністичні топоси: зовнішній і внутрішній простір. По-перше, це протистояння проглядається на рівні зовнішній світ / внутрішній замкнений світ лікарні, що поєдналися лише через образ оповідача, якого «допускають» до себе хворі заради розваги. Саме оповідачеві дається можливість розгледіти особистісні простори героїв, оскільки вони закриті для загалу, але відкриті для наратора.

Замкнений простір лікарні символізує захищеність героїв від зовнішнього вор ожого світу, і прихід невідомої людини в будинок завжди означає «пер ехідв інший світ» (Гессе 434). Замок, у якому розміщується лікарня, що є у фольклорних джерелах символом неприступності і оселею знатного роду, у новелі символізує таємницю, відстороненість від реального, зовнішнього світу. Отже, невипадково саме 3 опису лікарні починається новела, і впродовж твору автор неодноразово повертається до змалювання інтер' єру чи екстер 'єру замка. Особливо у топосі лікарні виділяється локація «вітальні», одного із затишних місць цього простору: «When he had gone, the superintendent ushered me into a small and exceedingly neat parlor, containing, among other indications of refined taste, many books, drawings, pots of flowers, and musical instruments. A cheerful fire blazed 
upon the hearth» (Рое) та їдальні: «At six, dinner was announced; and my host conducted me into a large salle a manger, where a very numerous company were assembled» (Рое). Дослідники наголошують, що образ будинку - це ні що інше, як «просторовий образ душі» (Kendler 557), втілення колективної свідомості людей, які мешкають у ньому, тому не дивно, що із першої своєї зустрічі із меш канцями замка, наратор відчуває змішані почуття, які він не може пояснити.

Простір лікарні у новелі деталізується: грунтовно змальовується екстер 'єр, перше враження оповідача під час в 'їзду до лікарні, детально пр описується й інтер'єр, увага акцентується на вікнах у їдальні як мар керах «межі», що були завжди щільно зачиненими, відсутністю килима на підлозі, що є символ ом затишку в оселі тощо. «The dining-room itself, although perhaps sufficiently comfortable and of good dimensions, had nothing too much of elegance about it. For example, the floor was uncarpeted; The windows, too, were without curtains; the shutters, being shut, were securely fastened with iron bars, applied diagonally, after the fashion of our ordinary shop-shutters. The apartment, I observed, formed, in itself, a wing of the chateau, and thus the windows were on three sides of the parallelogram, the door being at the other. There were no less than ten windows in all» (Poe). $\Gamma \mathrm{pa}$ ничний простір межі локалізує в рецепції наратора сакральний пр остір кімнат лікарні, побутова наповненість яких тісно переплітається із долями персонажів, які опинилися за «межею».

Замкнений простір лікарні протиставлено зовнішньому простору ворожого зовнішнього світу, де одні люди налаштовані негативно щодо інших, несхожих на них. Показово, що попутник оповідача уникає контакту із божевільними, не хоче заїхати до клініки разом із героєм. Дуальність простору представлена і на протиставленні мотивів «розум / божевілля», які у творі тісно пер еплітаються та подаються чер ез ракурс бачення гер оя-протагоніста. Ці мотиви найбільш в иразно проявляються через випадкових персонажів, з якими обідає гол овний герой, оскільки не існує показника психічної норми, який би визначав божевілля персонажа. Відкритий фінал новели оголює протиріччя в душі гер оя, визначає конфлікт та «межу» між реальним та ірреальним хронотопом.

Для художнього простору характерний прийом іронії, за допомогою якого змальовуються пацієнти у лікарні. Вони портретуються гіперболізовано, що створює комічний ефект: гості одягнені у дороге вбрання, однак без смаку, ст оли «ломилися» від вишуканої їжі, якої б вистачило на значно більшу кількість народу (алюзія на Ф. Рабле «Гаргантюа і Пантагрюель»), навколо хаотично були розставлені свічки у срібних канделябрах, що засліплювали очі. У вітальні грав невеличкий оркестр, який своїми різкими звуками дратував гостя, але пр иносив задоволення оточуючим. Герой почуває себе не комфортно у цьому місці, водночас мешканці закладу отримують задоволення від того, що їх оточує.

У просторі досить детально виписана галерея душевнохворих людей. С еред них чоловік, котрийвважав себе англійським чайником і щор анку полірував себе замшею з крейдою, інший бачив себе ослом і відмовлявся їсти звичайну їжу. Його, однак, швидко вилікували, годуючи лише чортополохом. Третій вважав себе сиром і ходив із ножем, прохаючи інших відрізати від себе шмато- 
чок: «We had a patient, once upon a time, who very pertinaciously maintained himself to be a Cordova cheese, and went about, with a knife in his hand, soliciting his friends to try a small slice from the middle of his leg» (Рое). Виписані у новелі персонажі поповнюють когорту «маленьких» людей, проблеми яких у зовнішньому світі нікого не цікавлять. Проте, у цьому замкненому пр осторі вони почуваються комфортно серед таких, як вони самі.

Константним в оповіді $\epsilon$ історичний хронотоп, який проглядається через вікторіанську добу, яка плавно переходить у новий час, коли за допомогою психіатрії можна було вплинути на політичну ситуацію, наприклад, змістити із високих посад небажаних родичів. Це стає новим способом політичних репр есій. Наразі дослідники схиляються до думки, що у новелі Е. По зображує давню хворобу - шизофренію, яка була відомою і вивчалася ще у XIX столітті. Е. Альтшулер цитує новели Е. По та наводить додаткові докази того, що шизофренія широко поширилася в Свропі на початку XIX століття (Kendler 551).

Отже, у новелі «Система доктора Смолла і професора Піріа» Е. По спостерігаємо кілька типів хронотопу, основними з яких стають реальний та ір реальний. Часом відбувається їхня швидка зміна, оскільки саме головний гер ой, людина, що постійно перебуває на «межі», під дією нелогічності і хаосу, виформовує то один, то інший часопростір, які змінюються колоподібно та циклічно. Для iрреального часопростору характерні готичні мотиви, мотиви таємниці, гри, ідеального і реального світів, які стають константним у творі та окреслюють ту романтичну традицію, що характерна для творчості Е. По. Проте у творі вимальовується і реальний хронотоп, який втілюється через образ божевільних, постаті яких грунтовно виписані, як і їхнє перебування в психлікарні. Детально пр омальовані певні топоси: лікарні, вітальні, їдальні тощо. Сталими мотивами часопростору стають мотиви роздвоєння, дуальності, дзеркальності, які проявляються через опозицію «божевілля / розум» і визначають екзистенцію особистості.

\section{Література}

1. Бахтин М. М. Формы времени и хронотопа в романе. Вопросы литературы и эстетики: исследования разных лет. Москва: Художественная литература, 1975. С. 234-407.

2. Гессе Г. Душа ребенка. Собр. соч.: в 4-х т. Санкт-Петербург, 1994. Т. 1. С. 433-463.

3. Ковалев Ю. В. Эдгар Аллан По. Новеллист и поэт. Монография. Ленинград: Худож. лит., 1984. $296 \mathrm{c}$.

4. Кройчик Л. Е. Система журналистских жанров. Основы творческой деятельности журн алиста. Санкт-Петербург, 2000. С. 134-138.

5. Роднянская И. Б. Художественное время и художественное пространство. Литературная энциклопедия терминов и понятий. Москва: НПК «Интелвак», 2003. С. 772-780.

6. Kendler Kenneth S. Kraepelin and the differential diagnosis of dementia praecox and manicdepressive insanity. Comprehensive Psychiatry. Vol. 27, n. 6, 1986. P. 549-558.

7. Foucault M. Madness and Civilization: A History of Insanity in the Age of Reason. London \& New York : Routledge, 2006. 299 p.

8. Poe E. A. The System of Doctor Tarr and Professor Fether. In The Works of Edgar Allan Poe / E. A. Poe. Retrieved from: https://www.gutenberg.org/files/2150/2150-h/2150-h.htm\#link2H_ 4_0005 


\section{References}

1. Bahtin, M. M. "Formy vremeni i hronotopa $\mathrm{v}$ romane (Forms of time and chronotope in the novel)". Voprosy literatury i estetiki: issledovaniya raznyh let (Issues of Literature and Aesthetics). Moskva: Hudozhestvennaya literatura, 1975. 234-407. Print.

2. Gesse, G. Dusha rebenka (The Child's Soul). Sobr. soch.: v 4 t. Sankt-Peterburg, 1994. T. 1. 433-463. Print.

3. Kovalev, Yu. Edgar Allan Po. Novellist i poet (Novelist and Poet). Leningrad: Hudozh. lit., 1984. 296. Print.

4. Krojchik, L. "Sistema zhurnalistskih zhanrov (The system of journalistic genres)". Osnovy tvorcheskoj deyatel'nosti zhurnalista (Fundamentals of the creative activity of a journalist). Sankt-Peterburg, 2000. 134-138. Print.

5. Rodnyanskaya, I. "Hudozhestvennoe vremya i hudozhestvennoe prostranstvo (Artistic time and space)". Literaturnaya enciklopediya terminov $i$ ponyatij (Literary encyclopedia of terms and concepts). Moskva: NPK "Intelvak", 2003. 772-780. Print.

6. Kendler, Kenneth S. Kraepelin and the differential diagnosis of dementia praecox and manicdepressive insanity. Comprehensive Psychiatry. Vol. 27, n. 6, 1986. P. 549-558. Print.

7. Foucault, M. Madness and Civilization: A History of Insanity in the Age of Reason. London \& New York : Routledge, 2006. 299. Print.

8. Poe, E. The System of Doctor Tarr and Professor Fether. In The Works of Edgar Allan Poe / E. A. Poe. Retrieved from: https://www.gutenberg.org/files/2150/2150-h/2150-h.htm\#link2H_ 4_0005 Web. 25 Sep. 2020

\section{MOTIVE OF MADNESS AS AN INTEGRAL FACTOR OF THE CHRONOTOPE IN THE STORY "THE SYSTEM OF DOCTOR TARR AND PROFESSOR FETHER" BY E.A. POE}

\section{Nataliia Sherstiuk}

Department of Foreign Languages with Latin and Medical Terminology, Ukranian Medical Stomatological Academy, Poltava, Ukraine.

\section{Abstract}

Background: The article deals with the problem of mental disorders and analyzes the spatiotemporal features in the short story by American writer Edgar Allan Poe "The System of Doctor Tarr and Professor Fether".

Purpose: to provide a detailed analysis of the chronotope as a special way of influencing the reader and highlighting the spatio-temporal features in the short story.

Results: The analysis presented in this article shows the dual chronotope and the artistic realization of cases of practical psychiatry. A real and historical chronotopes are the main part of the psychological short story. A spatial topos forms the unique author's style. There are no obvious realtime markers in the short story that would reproduce the time of the literary work. The psychological factor is amplified and the signs of personal chronotope are distinguished.

There are motives of play and irrationality which are markers of real space-time and have dual features in the short story. The line between madness and common sense is absent because these ones have connection with each other. The motive "insane mind and healthy consciousness" is important in Edgar Poe's short stories. Madness is the game's form: it is the presence of rules, a certain logic and freedom of choice. The short story shows the opposition of the real and the surreal chronotopes, which form the shape of the complex artistic world of literary works. Unreality is projected through the Gothic tradition.

Discussion: Given analysis sheds some light on types of space-time in short story (real, mystical, historical, social). They associate with a deep psychologism, which makes it possible to recreate events and find the right solution to reveal the secret.

Keywords: E. Poe, "The System of Doctor Tarr and Professor Fether", motive, chronotope, time, space, narrative, topos, locus, madness. 
Vitae. Nataliia Sherstiuk is a Lecturer of Department of Foreign Languages with Latin Language and Medical Terminology at Ukranian Medical Stomatological Academy. Her areas of research interests include world literature, literary studies and critics.

Correspondence: nataliasherstiuk@ gmail.com

Надійшла до редакціії 29 вересня 2020 року. Рекомендована до друку 16 жовтня 2020 року. 